\title{
Intoxicação natural por Thiloa glaucocarpa em bovinos no oeste da Bahia
}

Maria Talita Soares Frade, Everaldo Henrique Souza do Vale, larla Marques da Cruz, Antônio Flávio Medeiros Dantas, Alonso Pereira Silva Filho

Universidade Federal do Oeste da Bahia (UFOB), Barra, BA, Brasil

*Autor correspondente

e-mail: maria.frade@ufob.edu.br

\section{Resumo}

Thiloa glaucocarpa, planta nefrotóxica conhecida no semiárido nordestino como sipaúba ou vaqueta, é uma importante causa de morte em bovinos na região nordeste. Apesar do conhecimento da toxicidade da planta, ainda ocorrem perdas anuais. 0 presente trabalho relata a intoxicação por Thiloa glaucocarpa em 33 bovinos no munícipio de Barra, oeste da Bahia. Foi realizada visita a campo na comunidade Vereda do Gavião após relato da morte de 28 bovinos com quadro de apatia, anorexia, anúria/oligúria, constipação, edemas na região de membro posterior e barbela, de evolução variável. Segundo o proprietário, os bovinos eram criados em piquete com pastagem nativa, e após o início das primeiras chuvas, no final de setembro de 2016, com aproximadamente 15 dias, foram soltos em área com predomínio de "vaqueta". Já era de conhecimento do proprietário a toxicidade da planta, mas ele acreditava que por estar com a "folha mais grossa/verde" não causaria intoxicação. Verificou-se na propriedade grande quantidade da planta e cinco bovinos doentes que, ao exame clínico, apresentavam apatia, edemas de barbela (1/5), de vulva e membro posterior (1/5), hematoquezia (1/5), decúbito (2/5), e que também vieram a óbito. Foi realizada a necropsia de uma vaca de oito anos de idade, mestiça de Nelore, que havia sido colocada no final de novembro em área com "vaqueta", permanecido por três dias, removida após o início dos sinais clínicos e que, posteriormente, entrou em decúbito e morreu em aproximadamente 10 dias. Macroscopicamente, observaram-se edemas de subcutâneo, principalmente na região posterior dos membros pélvicos, de mesentério, da gordura perirrenal e pulmonar. Havia também hidrotórax, ascite e hidropericárdio. 0 tecido perirrenal apresentavase com áreas avermelhadas e os rins estavam aumentados de volume, com superfície subcapsular pálida e levemente granular, com pontos avermelhados discretos. Ao corte, com áreas avermelhadas da cortical a pelve renal e também edema de pelve renal. Microscopicamente, as lesões significativas afetavam os rins, sendo observada dilatação tubular moderada, túbulos desprovidos de células e formação de cilindros 
granulosos, afetando principalmente túbulos contorcidos proximais. Em outras áreas havia regeneração epitelial tubular moderada. Havia, também, cilindros hialinos na luz de túbulos da região cortical e medular, fibrose e infiltrado linfoplasmocitário intersticial discreto. 0 predomínio da planta na área de pastagem, a evidência de ingestão e o início dos sinais clínicos após as primeiras chuvas intercorrentes associados às lesões macro e microscópicas foram determinantes para o diagnóstico de intoxicação por Thiloa glaucocarpa no rebanho bovino. Não há tratamento efetivo e como profilaxia recomenda-se a remoção dos animas de áreas com a planta após o início das primeiras chuvas. É importante a "desmitificação" junto aos produtores rurais quanto a não ocorrência da intoxicação quando a folha está "mais grossa", uma vez que a intoxicação ocorre independentemente do estágio da planta. 